JAMP: Jurnal Adminitrasi dan Manajemen Pendidikan Volume 1 Nomor 1 Maret 2018, Hal : 22-28

Tersedia Online di http:/journal2.um.ac.id/index.php/jamp/ ISSN $x x x x-x x x x$ (online)

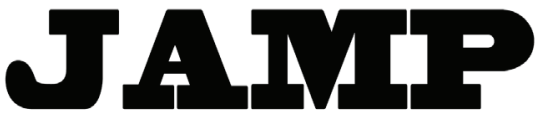

JURNAL ADMINISTRASI DAN MANAJEMEN PENDIDIKAN

\title{
ANALISIS ALOKASI ANGGARAN PENDIDIKAN DALAM ANGGARAN PENDAPATAN BELANJA DAERAH
}

\author{
Sri Citra Diah Nandani \\ Bambang Setyadin \\ Ahmad Nurabadi \\ Citranandani27@gmail.com \\ Universitas Negeri Malang, Jl. Semarang No. 5 Malang 65145
}

\begin{abstract}
This research aims to know education budget in Regional Revenue and Expenditure Budget (APBD) Year of 2010-2015 Ponorogo Regency, analyze the development of education budget, and describe proportion of education budget allocation with employe expenditure in APBD. This research used explanatory descriptive method. Data analysis in education budget assessed by comparing total number of APBD Education with APBD. The research result found that level of APBD Education in APBD Ponorogo Regency Year of 2010-2015 has no fluctuation, rather than developed linearly. Education budget in Ponorogo Regency is more than $20 \%$, which is about $51.24 \%$. The result of proportion between indirect expenditure showed larger result than direct expenditure.
\end{abstract}

Keywords: personnel expenditure, direct expenditure, capital expenditure

\begin{abstract}
Abstrak: Penelitian ini bertujuan untuk mengetahui anggaran pendidikan dalalam APBD tahun 2010-2015 di Kabupaten Ponorogo, menganalisis perkembangan anggaran pendidikan, dan mendeskripsikan proporsi alokasi anggaran pendidikan dengan belanja pegawai dalam APBD. Penelitian ini menggunakan metode deskriptif eksplanatori. Analisis data dalam anggaran pendidikan dihitung dengan cara membandingkan jumlah total APBD Pendidikan dengan APBD. Hasil dari penelitian bahwa tingkat APBD Pendidikan dalam APBD Kabupaten Ponorogo Tahun 2010-2015 tidak mengalami fluktuasi, melainkan berkembang secara linier. Aanggran pendidikan Kabupaten Ponorogo lebih dari 20\% yaitu rata-rata sebesar 51,24\%. Hasil proporsi antara belanja tidak langsung lebih besar dibandingkan dengan belanja langsung.
\end{abstract}

Kata kunci: belanja pegawai, belanja langsung, belanja modal

Penyelenggaraan pendidikan untuk kemajuan bangsa memerlukan biaya paling tidak memenuhi pembiayaan untuk memberikan standar pelayanan. Biaya pendidikan merupakan komponen sangat penting dalam penyelenggaraan pendidikan. Proses pendidikan tidak dapat berjalan tanpa biaya, sehingga perlu ada dukungan dari pemerintah, seperti Anggaran Pendapatan Belanja Daerah untuk pendidikan. Menurut Supriadi (2004: 3), Biaya (cost) dalam pengertian ini memiliki cakupan luas, yakni semua jenis pengeluaran yang berkenaan dengan penyelenggaraan pendidikan, baik dalam bentuk uang maupun barang dan tenaga. Sementara menurut Fattah (2002: 49), Anggaran sendiri terdiri dari dua sisi, penerimaan dan pengeluaran. Sisis penerimaan berisi besaranya dana yang diterima dari setiap sumber dana, sedangkan sisi pengeluaran berisi alokasi besarnya biaya pendidikan yang harus dibiayai.

Menurut Bastian (2006: 189), Anggaran Pendapatan Belanja Daerah (APBD) merupakan "rencana kerja pemerintah daerah dalam bentuk satuan uang untuk kurun waktu satu tahun tahunan dan berorientasi pada tujuan kesejahteraan publik". APBD merupakan dasar pengelolaan keuangan daerah dalam satu 
tahun anggaran. APBD merupakan rencana pelaksanaan semua pendapatan daerah dan semua belanja daerah dalam rangka pelaksanaan desentralisasi dalam tahun anggaran. Menurut Undang-Undang Nomor 17 Tahun 2003 tentang Keuangan Negara, "APBD adalah daftar terperinci mengenai pendapatan dan pengeluaran daerah dalam satu tahun yang telah disahkan Dewan Perwakilan Rakyat Daerah (DPRD)".

Terkait dengan pendanaan bidang pendidikan, pemerintah telah menetapkan ketentuan, bahwa alokasi dana untuk pendidikan 20\% dari APBD. Hal ini tercantum dalam Undang-Undang Nomor 20 Tahun 2003 tentang Sistem Pendidikan Nasional Pasal 49 Ayat 1, yaitu "Dana pendidikan selain gaji pendidik dan Anggaran Pendapatan dan Belanja Negara (APBN) pada sektor pendidikan dan minimal $20 \%$ dari APBD".

Pendapatan ekonomi yang berbeda-beda di setiap wilayah menyebabkan melambatnya kebijakan yang dilakukan pemerintah untuk pendidikan. Di sini menjadi tugas pemerintah untuk menyelesaikan persoalan-persoalan tersebut. Pemerintah harus mengawasi agar anggaran pendidikan benar-benar sudah disalurkan secara merata.

Berdasarkan uraian di atas dapat disimpulkan, bahwa setiap warga negara berhak mendapatkan pendidikan. Pemerintah ikut bertanggungjawab atas pendidikan warga negaranya. Pemerintah wajib membiayai pendidikan setiap warga negaranya dengan anggaran pendidikan minimal 20\% dari APBD. Dengan demikian diharapkan setiap warga negara dapat memiliki kesempatan untuk mendapatkan pendidikan setinggi mungkin.

Dengan kenaikan jumlah alokasi anggaran pendidikan diharapkan terjadi pembaharuan visi, misi, dan strategi pembangunan pendidikan nasional. Pendidikan nasional mempunyai visi terwujudnya sistem pendidikan sebagai pranata sosial yang kuat dan berwibawa untuk memberdayakan semua Warga Negara Indonesia berkembang menjadi manusia yang berkualitas, sehingga mampu dan proaktif menjawab tantangan zaman yang selalu berubah.

Menurut Undang-Undang Nomor 12 tahun 2007 tentang Rencana Pembangunan Jangka Panjang anggaran pada fungsi pendidikan memiliki sasaran, yaitu: (1) Meningkatnya taraf pendidikan penduduk, (2) Meningkatnya rata-rata lama sekolah penduduk anak usia 15 tahun ke atas, (3) Meningkatnya Angka Partisipasi Murni Sekolah Menenggah Pertama (SMP), (4) MeningkatnyaAngka Partisipasi Kasar Sekolah Menenggah Atas (SMA), (5) Meningkatnya kualitas dan relevansi pendidikan, (6) Meningkatnya kualifikasi dan kompetensi guru, dosen, dan tenaga kependidikan.

Pendapatan Asli Daerah Kabuaten Ponorogo tahun 2015 sebesar 31.784.078.707,87. Alokasi anggaran pendidikan Kabupaten Ponorogo dari tahun ke tahun perlu dianalisis. Oleh karena itu perlu dilakukan penelitian, karena pendapatan ekonomi setiap daerah berbeda-beda dan aturan pemerintah yang memberlakukan 20 persen anggaran pendidikan dari APBD, maka peneliti ingin melakukan penelitian ini untuk mengetahui apakah anggaran pendidikan di Kabupaten Ponorogo sudah sesuai dengan aturan pemerintah, yaitu sebesar $20 \%$, atau kurang dari $20 \%$. Penelitian ini juga ditujukan untuk mengetahui bagaimana proses berjalannya anggaran pendidikan. Oleh sebab itu penelitian ini penting untuk digunakan sebagai pengawasan dalam berjalannya Anggaran Pendidikan.

\section{METODE}

Penelitian ini menggunakan rancangan ex post facto karena peneliti hanya mengambil data Anggaran Pendidikan dari tahun 2010-2015 yang selanjutnya disimpulkan sehingga menjadi kesimpulan. Penelitian ini menggunakan penggumpulan data dengan teknik dokumentasi. Informasi bisa diperoleh lewat fakta yang tersimpan dalam bentuk data berupa dokumen.

\section{HASIL}

Anggaran Pendapatan Belanja Daerah (APBD) merupakan dasar pengelolan keuangan daerah dalam satu tahun anggaran. APBD merupakan rencana pelaksanaan semua Pendapatan Daerah dan Semua Belanja Daerah dalam tahun anggaran tertentu. APBD yang dialokasikan untuk pendidikan di 
Kabupaten Ponorogo pada Tahun 2010-2015.

Tabel 1 APBD Kabupaten Ponorogo Tahun 2010-2015 (Dalam Jutaan)

\begin{tabular}{llll}
\hline Tahun Anggaran & $\begin{array}{l}\text { Belanja Tidak Langsung } \\
(\mathrm{Rp})\end{array}$ & $\begin{array}{l}\text { Belanja Langsung } \\
(\mathrm{Rp})\end{array}$ & $\begin{array}{l}\text { Total APBD Kabupaten } \\
\text { Ponorogo (Rp) }\end{array}$ \\
\hline 2010 & $\mathbf{7 1 0 . 7 1 5 . 6 6 2}$ & $\mathbf{2 2 6 . 1 1 2 . 9 6 2}$ & $\mathbf{9 0 5 . 0 7 2 . 6 2 3}$ \\
2011 & $\mathbf{7 8 6 . 2 7 1 . 9 4 5}$ & 325.883 .904 & 1.064 .975 .214 \\
2012 & $\mathbf{8 8 9 . 1 5 0 . 7 0 5}$ & 427.031 .636 & $\mathbf{1 . 2 5 6 . 7 0 8 . 0 1 9}$ \\
2013 & $\mathbf{1 . 0 3 8 . 1 9 3 . 4 7 7}$ & 415.523 .304 & 1.425 .892 .462 \\
2014 & 1.123 .561 .687 & 630.489 .277 & 1.642 .602 .239 \\
2015 & 1.350 .553 .656 & 713.612 .852 & 1.864 .337 .393 \\
\hline
\end{tabular}

Sumber data: Badan Pengelola Keuangan dan Aset Daerah Kabupaten Ponorogo Tahun 2010-2015.

Tabel 2 APBD Pendidikan Kabupaten Ponorogo Tahun 2010-2015 (Dalam Jutaan)

\begin{tabular}{llll}
\hline Tahun Anggaran & $\begin{array}{l}\text { Belanja Tidak Langsung } \\
(\text { Rp) }\end{array}$ & $\begin{array}{l}\text { Belanja Langsung } \\
(\text { Rp) }\end{array}$ & $\begin{array}{l}\text { Total Anggaran } \\
\text { Pendidikan Kabupaten } \\
\text { Ponorogo (Rp) }\end{array}$ \\
\hline 2010 & 448.456 .680 & 4.267 .722 & 493.724 .403 \\
2011 & 501.289 .868 & 109.796 .759 & 611.086 .628 \\
2012 & 596.353 .791 & 63.965 .547 & 660.319 .338 \\
2013 & 700.036 .738 & 42.330 .170 & 742.366 .908 \\
2014 & 757.310 .814 & 51.675 .286 & 808.986 .100 \\
\hline 2015 & $\mathbf{8 0 1 . 7 7 4 . 0 0 1}$ & 46.303 .899 & $\mathbf{8 4 8 . 0 7 7 . 9 0 1}$ \\
\hline
\end{tabular}

Sumber data: Badan Pengelola Keuangan dan Aset Daerah Kabupaten Ponorogo Tahun 2010-2015

Berdasarkan data di atas tingkat fluktuasi anggaran pendidikan cenderung linear seiring dengan meningkatnya APBD Kabupaten Ponorogo. Hal tersebut dapat diketahui dengan terus meningkatnya anggaran pendidikan dari tahun ke tahun.

Tabel 3 APBD dan APBD Pendidikan Kabupaten Ponorogo Tahun 2010-2015 (Dalam Jutaan)

\begin{tabular}{lllll}
\hline Tahun & APBD & APBD Pendidikan & $\%$ & Selisih 20\% \\
\hline 2010 & $\mathbf{9 0 5 . 0 7 2 . 6 2 3}$ & 493.724 .403 & 54,55 & 34,55 \\
2011 & $\mathbf{1 . 0 6 4 . 9 7 5 . 2 1 4}$ & $\mathbf{5 7 1 . 1 5 1 . 9 3 5}$ & $\mathbf{5 3 , 6 0}$ & 33,6 \\
2012 & $\mathbf{1 . 2 5 6 . 7 0 8 . 0 1 9}$ & $\mathbf{6 6 0 . 3 1 9 . 3 3 8}$ & $\mathbf{5 2 , 5 4}$ & $\mathbf{3 2 , 5 4}$ \\
2013 & $\mathbf{1 . 4 2 5 . 8 9 2 . 4 6 2}$ & $\mathbf{7 4 2 . 3 6 6 . 9 0 8}$ & $\mathbf{5 2 , 0 6}$ & $\mathbf{3 2 , 0 6}$ \\
2014 & $\mathbf{1 . 6 4 2 . 6 0 2 . 2 3 9}$ & $\mathbf{8 0 8 . 9 8 6 . 1 0 0}$ & 49,25 & $\mathbf{2 9 , 2 5}$ \\
\hline 2015 & $\mathbf{1 . 8 6 4 . 3 3 7 . 3 9 3}$ & $\mathbf{8 4 8 . 0 7 7 . 9 0 1}$ & 45,49 & 25,49 \\
\hline
\end{tabular}

Sumber data: Badan Pengelola Keuangan dan Aset Daerah Kabupaten Ponorogo Tahun 2010-2015

Dari tabel tersebut dapat diketahui bahwa anggaran pendidikan mengalami peningkatan seiring dengan meningkatnya APBD Kabupaten Ponorogo. 


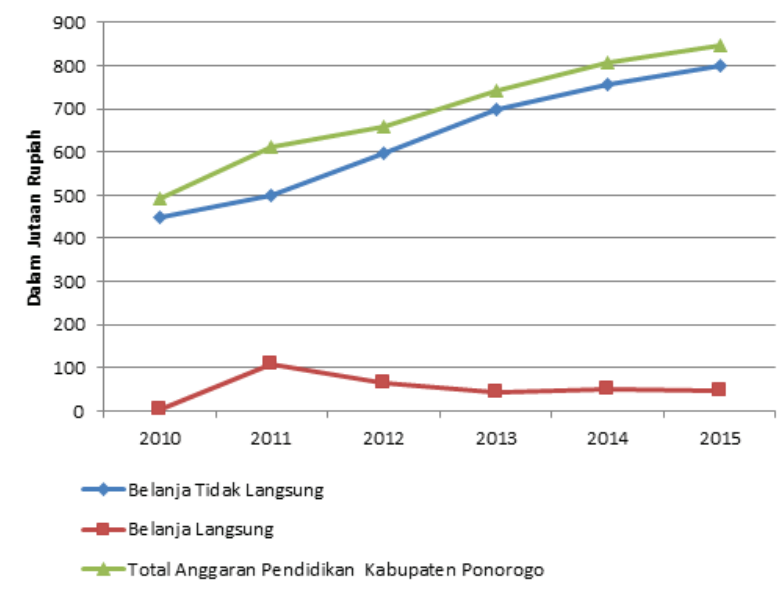

Gambar 1 Proporsi Anggaran Pendidikan, Belanja Langsung, dan Belanja Tidak Langsung Tahun 2010-2015

Dari gambar tersebut dapat diketahui bahwa belanja langsung dan tidak langsung dalam sektor anggaran pendidikan Kabupaten Ponorogo setiap tahunnya mengalami peningkatan. belanja tidak langsung dalam belanja pegawai di sini meliputi gaji dan tunjangan, gaji pokok pegawai negeri sipil, tunjangan keluarga, tunjangan jabatan, tunjangan fungsional, dan tunjangan profesi guru. Sedangkan belanja langsung dalam belanjai pegawai meliputi honorer pegawai negeri sipil, honorer tim pengadaan barang dan jasa, dan honorer non PNS. Untuk belanja barang dan jasa meliputi belanja bahan habis pakai kantor, belanja alat tulis kantor, dan belanja cetak serta fotocopy. Untuk belanja modal meliputi belanja modal pengadaan konstruksi atau pembelian bangunan, belanja modal pengadaan konstruksi bangunan gedung pendidikan, belanja modal pembelian alat-alat laboratorium serta peraga, belanja modal pengadaan komputer dan sebagainya.

\section{PEMBAHASAN}

Sumber pembiayaan pendidikan secara makro telah diatur dalam pasal 31 Undang-undang 1945 yang mengamanatkan pemerintah pusat dan daerah bertanggung jawab menyediakan anggaran pendidikan. Pembiayaan pendidikan tidak boleh lepas dari kebijakan keuangan negara. Asumsi yang lain ialah bahwa kegiatan pendidikan adalah dalam rangka pencapaian tujuan pemangunan nasional. Menurut Antonio (2012), Semakin tinggi tingkat suku bunga, semakin tinggi juga harga yang di tetapkan pada suatu barang. Tingkat suku bunga diikuti dengan tingkat inflasi mata uang semakin mengkhawatirkan pelaku pasar karena resiko investasi yang akan mereka terima semakin tinggi.

Dari data sebelumnya dapat disimpulkan perkembangan anggaran pendidikan Kabupaten Ponorogo berkembang secara linier seiring dengan berkembangnya jumlah APBD Kabupaten Ponorogo. Hal ini terbukti setiap tahunnya anggaran pendidikan di Kabupaten Ponorogo cenderung mengalami peningkatan. Jika dikaitkan dengan pertumbuhan perekonomian di Indonesia, anggran pendidikan tidak mengalami fluktuasi. Hal ini sejajar seiring dengan pertumbuah perekonomian di Indonesia sehingga tidak mengalami gejolak. APBD Pendidikan dalam APBD Kabupaten Ponorogo Tahun 2010-2015 cenderung linear menurun, dengan kata lain tidak terjadi fluktuasi anggaran pendidikan dalam struktur APBD Kabupaten Ponorogo dari tahun 2010- 2015 seiring dengan meningkatnya APBD Kabupaten Ponorogo.

Pada tahun 2010 anggaran pendidikan mencapai 54,55\%, tahun berikutnya yaitu tahun 2011 menurun menjadi 53,60\% dengan penurunan sebesar 0,95\%. Pada tahun 2012 anggaran pendidikan menurun 1,06\% dengan anggaran sebesar 52,54\%. Di tahun 2013 anggaran mengalami sedikit penurunan dengan perbedaan $0,48 \%$ dengan jumlah anggaran sebesar 52,06\%. Tahun 2014 anggaran pendidikan mencapai 49,25\% jumlah ini mengalami penurunan sebesar 2,81\%. Sedangkan pada tahun 2015 anggaran pendidikan mencapai 45,49\% dengan penurunan sebesar 3,76\%. Salah satu kunci peningkatan 
kualitas pendidikan adalah dengan kebijakan anggaran. Pembangunan pendidikan merupakan bagian penting dari upaya pemerintah untuk meningkatkan kesejahteraan masyarakat. Pendidikan mendapat perhatian khusus dari pemerintah karena merupakan pilar utama dalam pengembangan manusia untuk menciptakan masyarakat yang cerdas.

Setelah di analisis anggaran pendidikan di Kabupaten Ponorogo pada tahun 2010 APBD pendidikan mencapai 54,55\% meningkat 34,55\% lebih besar dibandingkan dengan ketentuan pemerintah sebesar 20\%. Pada tahun selanjutnya, yaitu tahun 2011 APBD pendidikan mencapai 53,60\% meningkat $33,6 \%$ dari ketentuan yang hanya $20 \%$. Berikutnya tahun 2012 APBD pendidikan mencapai $52,54 \%$ dengan peningkatan sebesar 32,54\%. Untuk tahun 2013 APBD pendidikan sebesar 52,06\% meningkat sebesar 32,06\%. Pada tahun 2014 APBD pendidikan mencapai 49,25\% meningkat $29,25 \%$ dan di tahun 2015 APBD pendidikan sebesar 45,49\% meningkat sebesar 25,49\%. Dari perolehan tersebut memang jumlah APBD sudah memenuhi dari peraturan pemerintah. Sesuai dengan putusan Mahkamah Konstitusi Nomor 13/PUU-VI I 2008, pemerintah memiliki tugas untuk: Pemerintah harus menyediakan anggaran pendidikan sekurang-kurangnya $20 \%$ dari APBN dan APBD untuk memenuhi kebutuhan penyelenggaraan pendidikan nasional.

Berdasarkan hasil analisis mengenai tingkat perkembangan anggaran sektor pendidikan dalam APBD Kabupaten Ponorogo Tahun 2010-2015 menunjukkan, bahwa APBD Pendidikan memiliki proporsi yang tinggi dapat dikatakan demikian karena APBD Pendidikan mencapai lebih besar dari 20\% dengan keputusan pemerintah yang menyebutkan minimal APBD Pendidikan adalah $20 \%$, dimana tingkat persentase tersebut menunjukkan tingkat kepedulian pemerintah daerah dalam upaya mengembangkan pendidikan di Kabupaten Ponorogo. Kepedulian tersebut dapat ditujukkan dari tersedianya sarana dan prasarana fasilitas pendidikan sesuai dengan tingkat kebutuhan yang disediakan oleh daerah. Anggaran pendidikan di Kabupaten Ponorogo sudah memenuhi dengan ketetapan pemerintah. Ini membuktikan bahwa Kabupaten Ponorogo mampu memenuhi penganggaran pendidikan yang telah ditetapkan oleh pemerintah. Kabupaten Ponorogo sudah menjalankan sebagai mana mestinya kepedulian terhadap pendidikan.

Anggaran berisi rencana kegiatan yang dipresentasikan dalam bentuk rencana pendapatan belanja dalam satuan moneter. Dalam bentuk yang paling sederhana anggaran merupakan suatu dokumen yang menggambarkan kondisi keuangan dari organisasi yang meliputi informasi mengenai pendapatan belanja dan aktivitas. Anggaran berisi estimasi mengenai apa yang akan dilakukan organisasi di masa yang akan datang. Menurut Baswir (2006: 26), Anggaran Negara diartikan sebagai suatu pernyataan tentang perkiraan pengeluaran dan penerimaan yang diharapkan akan terjadi dalam suatu periode dimasa depan, serta data dan pengeluaran dan penerimaan yang sungguh terjadi di masa lalu.

Di dalam penganggran pendidikan Kabupaten Ponorogo antara belanja langsung dan tidak langsung pada tahun 2010-2015 anggaran belanja tidak langsung yang cenderung lebih besar dibandingkan dengan belanja langsung. Rata-rata hampir $90 \%$ anggaran yang dikeluarkan untuk belanja tidak langsung. Belana tidak langsung merupakan anggaran yang dikeluarkan untuk membiayai pegawai. Ini dikarenakan di dalam belanja tidak langsung terdiri atas gaji dan tunjangan, gaji pokok pegawai negeri sipil, tunjangan keluarga, tunjangan jabatan, tunjangan fungsional, dan tunjangan profesi guru.

Hal ini sangatlah wajar menginggat banyaknya guru, staf dan karyawan yang ikut membantu dalam perkembangan pendidikan di Kabupaten Ponorogo. Apabila kualitas guru, staf dan karyawan baik makan diharapkan kualitas pendidikan di Kabupaten Ponorogo juga mengalami peningkatan ke arah yang lebih baik, maka menunjukkan keberhasilan Kabupaten Ponorogo dalam bidang pendidikan.

\section{KESIMPULAN DAN SARAN}

\section{Kesimpulan}

Tingkat fluktuasi APBD Pendidikan dalam APBD Kabupaten Ponorogo Tahun 2010-2015 cenderung linear menurun, dengan kata lain tidak terjadi fluktuasi artinya tidak ada gejolakkenaikan dan penurunan secara drastic pada tiap tahunnya di dalam anggaran pendidikan dalam struktur APBD 
Kabupaten Ponorogo dari tahun 2010- 2015 seiring dengan meningkatnya APBD Kabupaten Ponorogo. Pada tahun 2010 anggaran pendidikan mencapai 54,55\%, tahun berikutnya yaitu tahun 2011 menurun menjadi 53,60\% dengan penurunan sebesar $0,95 \%$. Pada tahun 2012 anggaran pendidikan menurun $1,06 \%$ dengan anggaran sebesar 52,54\%. Di tahun 2013 anggaran mengalami sedikit penurunan dengan perbedaan 0,48\% dengan jumlah anggaran sebesar 52,06\%. Tahun 2014 anggaran pendidikan mencapai $49,25 \%$ jumlah ini mengalami penurunan sebesar 2,81\%. Sedangkan pada tahun 2015 anggaran pendidikan mencapai 45,49\% dengan penurunan sebesar 3,76\%.

Setelah dianalisis anggaran pendidikan di Kabupaten Ponorogo Tahun 2010-2015 sudah sesuai dengan keputusan pemerintah dan memenuhi Undang- Undang Nasional yang menetapkan minimal anggaran pendidikan sebesar 20\%. Hal tersebut terbukti di tahun 2010 anggaran pendidikan sebesar $54,55 \%$ menggalami peningkatan $34,55 \%$ dibandingkan ketentuan pemerintah yang hanya $20 \%$, tahun 2011 anggaran pendidikan sebesar 53,60\% mengalami peningkatan 33,6\% dibandingkan ketentuan pemerintah yang hanya 20\%, tahun 2012 anggaran pendidikan sebesar 52,54\% meningkat sebesar $32,54 \%$ dibandingkan ketentuan pemerintah yang hanya 20\%, tahun 2013 anggaran pendidikan sebesar $52,06 \%$ dengan peningkatan sebesar $32,06 \%$ dibandingkan ketentuan pemerintah yang hanya $20 \%$, tahun 2014 anggaran pendidikan sebesar 49,25\% meningkat 29,25\% dibandingkan ketentuan pemerintah yang hanya $20 \%$, dan tahun 2105 anggaran pendidikan sebesar $45,49 \%$ meningkat sebesar $25,49 \%$ dibandingkan ketentuan pemerintah yang hanya $20 \%$.

Proporsi Anggaran Sektor Pendidikan Antara Biaya Langsung dan Tidak Langsung Tahun 2010: menunjukkan, bahwa biaya tidak langsung dalam hal ini belanja pegawai memiliki persentase terbesar, yaitu 90,83\% sedangkan belanja barang dan jasa yang termasuk belanja langsung memiliki persentase terendah, yaitu sebesar $0,22 \%$. Jika di bandingkan dengan ketentuan pemerintah yang menetapkan $20 \%$ untuk anggaran pendidikan maka untuk tahun 2010 anggaran pendidikan meningkat sebesar 34,55\%. Akan tetapi jumlah itu lebih besar untuk biaya tidak langsung.

Tahun 2011 menunjukkan, bahwa biaya tidak langsung dalam hal ini belanja pegawai memiliki persentase terbesar, yaitu $87,77 \%$ sedangkan belanja barang dan jasa yang termasuk belanja langsung memiliki persentase terendah, yaitu sebesar $0,16 \%$. Jika di bandingkan dengan ketentuan pemerintah yang menetapkan 20\% untuk anggaran pendidikan maka untuk tahun 2011 anggaran pendidikan meningkat sebesar 33,6\%. Akan tetapi jumlah itu lebih besar untuk biaya tidak langsung. Tahun 2012 menunjukkan, bahwa biaya tidak langsung dalam hal ini belanja pegawai memiliki persentase terbesar, yaitu 90,31\% sedangkan belanja barang dan jasa yang termasuk belanja langsung memiliki persentase terendah, yaitu sebesar $0,20 \%$. Jika di bandingkan dengan ketentuan pemerintah yang menetapkan $20 \%$ untuk anggaran pendidikan maka untuk tahun 2012 anggaran pendidikan meningkat sebesar 32,54\%. Akan tetapi jumlah itu lebih besar untuk biaya tidak langsung. Tahun 2013 menunjukkan, bahwa biaya tidak langsung dalam hal ini belanja pegawai memiliki persentase terbesar, yaitu 94,29\% sedangkan belanja barang dan jasa yang termasuk belanja langsung memiliki persentase terendah, yaitu sebesar $0,27 \%$. Jika di bandingkan dengan ketentuan pemerintah yang menetapkan $20 \%$ untuk anggaran pendidikan maka untuk tahun 2013 anggaran pendidikan meningkat sebesar 32,06\%. Akan tetapi jumlah itu lebih besar untuk biaya tidak langsung. Tahun 2014 menunjukkan, bahwa biaya tidak langsung dalam hal ini belanja pegawai memiliki persentase terbesar, yaitu $93,61 \%$ sedangkan belanja pegawai yang termasuk belanja langsung memiliki persentase terendah, yaitu sebesar $0,27 \%$. Jika di bandingkan dengan ketentuan pemerintah yang menetapkan $20 \%$ untuk anggaran pendidikan maka untuk tahun 2014 anggaran pendidikan meningkat sebesar $29,25 \%$. Akan tetapi jumlah itu lebih besar untuk biaya tidak langsung. Tahun 2015 menunjukkan, bahwa biaya tidak langsung dalam hal ini belanja pegawai memiliki persentase terbesar, yaitu $94,54 \%$ sedangkan belanja pegawai yang termasuk belanja langsung memiliki persentase terendah, yaitu sebesar $0,27 \%$. Jika di bandingkan dengan ketentuan pemerintah yang menetapkan 20\% untuk anggaran pendidikan maka untuk tahun 2015 anggaran pendidikan meningkat sebesar 25,49\%. Akan tetapi jumlah itu lebih besar untuk biaya tidak langsung. 


\section{Saran}

Berdasarkan hasil penelitian dan analisis peneliti dapat memberikan saran sebagai berikut: (1) Bagi Pimpinan Dewan Perwakilan Rakyat Daerah (DPRD) Kabupaten Ponorogo dan anggotanya untuk lebih mempertahankan stabilitas anggaran tahun-tahun yang akan datang; (2) Bagi Pimpinan Badan Pengelolaan dan Aset Daerah (BPKD) Kabupaten Ponorogo untuk lebih memperdulikan dalam perkembangan dan perbaikan dalam pendidikan;(3)Bagi Kepala Dewan Pendidikan Kabupaten Ponorogo, agar mempertimbangkan untuk mengusulkan kepada pemerintah daerah agar supaya mempertahankan stabilitas anggaran pendidikan serta memperhatikan pada anggaran pendidikan; (4) Bagi Kepala Pemerintah Daerah Kabupaten Ponorogo lebih memfokuskan perhatiannya dalam pengelolaan APBD khususnya Pendidikan; (5) Bagi ketua Jurusan Administrasi Pendidikan untuk memperhatikan dalam penganggaran pendidikan pada tingkat lokal dan mengembangkan kajian pendidikan.

\section{DAFTAR RUJUKAN}

Bastian, I. 2006. Akutansi Sektor Publik. Jakarta: Erlangga.

Mahkamah Konstitusi Nomor 13/PUU-VI I 2008. Anggaran Pendidikan.

Peraturan Menteri Dalam Negeri Nomor 13 tahun 2006. Jakarta: Ciptamedia.

Supriadi, D. 2004. Peningkatan Kualitas Layanan, Jurnal Pendidikan Vol. 1 No.1.

Undang-Undang Nomor 17 Tahun 2003 tentang Keuangan Negara. Jakarta: Ciptamedia.

Undang-Undang Nomor 20 Tahun 2003 tentang Sistem Pendidikan Nasional Pasal 49 Ayat 1. Jakarta: Ciptamedia.

Undang-Undang Nomor 33 Tahun 2004 tentang Perimbangan Keuangan Antara Pusat dan Pemerintah Daerah. Jakarta: Ciptamedia. 